\title{
ET SANT OG LEVENDE BILDE AV VERDEN; VERDENSUTSTILLINGER OG MUSEUMSHISTORIE
}

\section{Brita Brenna}

Gentlemen, The Exhibition of 1851 is to give us a true test and a living picture of the point of development at which the whole of mankind has arrived [...], and a new starting point from which all nations will be able to direct their further exertions. ${ }^{2}$

...anthropological humanism begins with the different and renders it - through naming, classifying, describing, interpreting - comprehensible. It familiarizes. An ethnographic surrealist practice, by contrast, attacks the familiar, provoking the irruption of otherness - the unexpected. The two attitudes presuppose each other; both are elements within a complex process that generates cultural meanings, definitions of self and other. ${ }^{3}$

Norge var en svart ivrig deltaker på verdensutstillinger i forrige ärhundre - fram til 1905. Landet har vart representert på senere utstillinger, men kun unntaksvis kan innsatsen sammenliknes med de kraftanstrengelsene som la bak deltakelsen for unionen med Sverige ble opplost. I perioden fra 1851 til 1900 deltok Norge på alle de ti utstillingene som regnes $i$ klassen for verdensutstillinger. Utstillinger som ble holdt $i$ London, Wien, Philadelphia, Chicago og hele fire ganger i Paris. Norge deltok også pà en rekke andre internasjonale spesialutstillinger med temaer som fiskeri, hygiene, geografi, skipsfart og elektrisitet. Det var en underlig idé à sende alskens folklore, teknologi og kunst på representasjonsreise til byer rundt i verden, og det vil vare utgangspunktet mitt her: Det spesielle ved à stille ut all verdens ting vil jeg prøve à finne ut av ved a gå til museumshistorie. Hvilke bidrag kan museologi gi til studier av den norske utstillingsdeltakelsen?"

Den norske deltakelsen på verdensutstillingene var omfattende og kostbar, og deltakelsen var i stor grad offentlig finansiert: Stortinget bevilget penger til å dekke omkostningene ved å sende gjenstander, til kommissærer i landene utstillingene ble holdt, til egne paviljonger og vakthold og til utsmykning av de ulike avdelingene. En viktig forklaring av denne utstillingsviljen ligger i Norges manglende mulighet til å drive utenrikspolitikk i unionen med Sverige. I den økonomiske og politiske eli- 
B RITA BRENNA

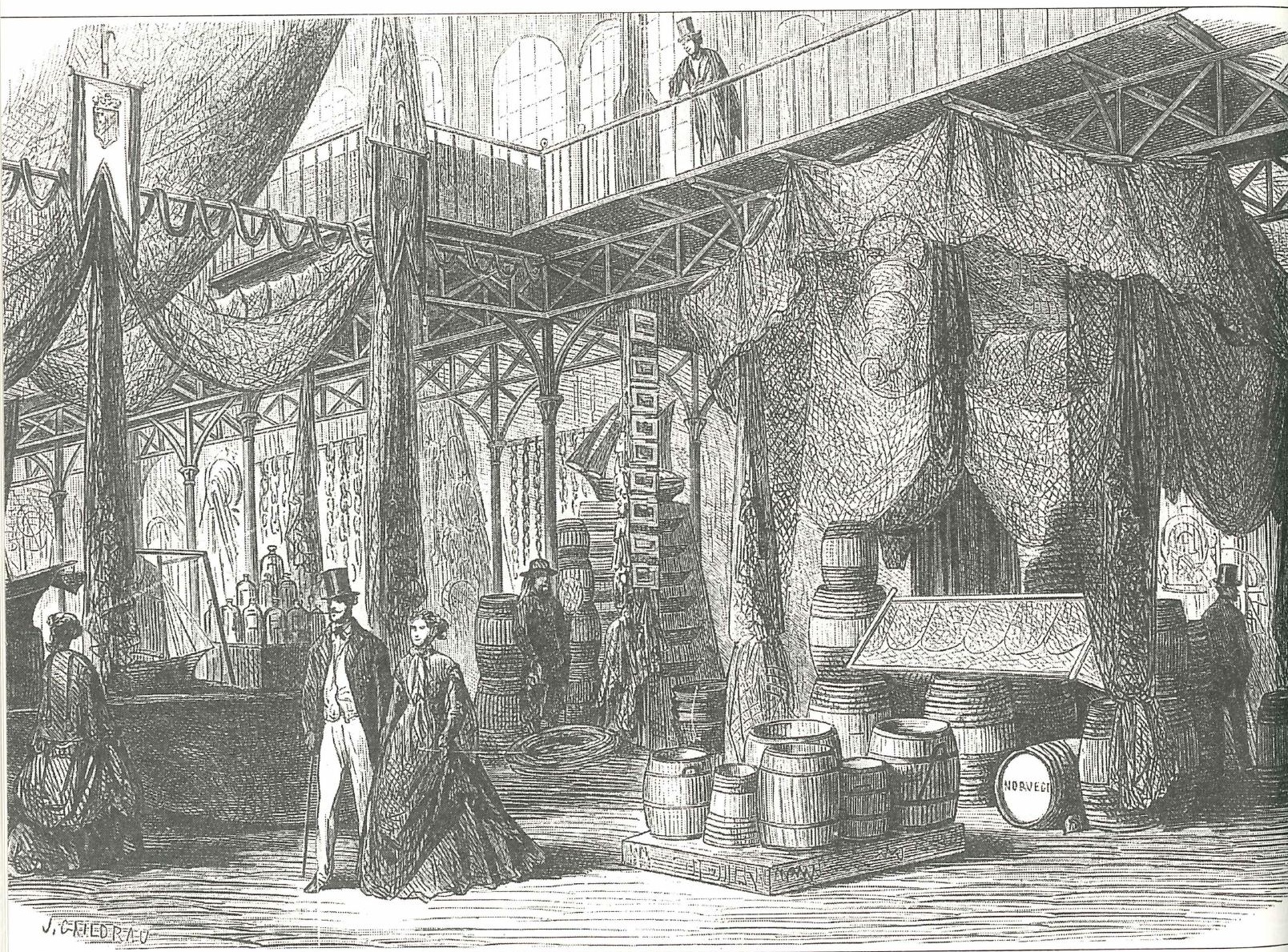

Over: Norske fiskerier under verdensutstillingen i 1867 . Denne illustrasjonen og oversiktsmotivet over hele verdensutstillingen er fra: Exposition universelle de 1867 illustre. Publication internationale autoriseé parla commission impériale Paris 1867.

ten var det også en drivende vilje til modernisering, til å utvikle landet etter mønster fra det store utland. Kunnskapen og kontaktene som ble innhentet på verdensutstillingene bragte både nye kulturelle og materielle kapitaler til norske bedrifter. Men deltakelsen på verdensutstillingene var en kompleks affære med mange involverte aktører: De menneskelige aktø- rene var blant andre utstillere, organisatorer, byråkrater, politikere og tilskuere. Objektene som ble stilt ut, de ikke-menneskelige aktørene, var for eksempel håndarbeid, maskiner, malerier, antikviteter, skulpturer, råvarer og industriprodukter. Dette mangfoldet er fascinerende og viktig - og hvorfor akkurat disse aktørene var involvert og hvilken rolle de spilte opptar 
meg. Men min avhandling om den norske deltakelsen er langt fra ferdig, og jeg skal ikke presentere noen endelig konklusjoner her. ${ }^{4}$ Snarere vil jeg trekke fram verdensutstillingenes tilknytning til og fellestrekk med andre utstillingsformer og -institusjoner og søke etter teorihistorier som kan hjelp meg å se det underlige, det fremmede og ukjente $\mathrm{i}$ verdensutstillingene og $\mathrm{i}$ den norske deltakelsen.

For det å stille ut varer og ting var en relativt ny måte å representere både ver- den og seg selv på, og en ny måte å møte et publikum på, rundt midten av det forrige århundret. Hva var effektene av denne typen representasjon? Hva var forholdet mellom verdensutstillinger og andre museums- og utstillingsinstitusjoner? Hvordan ble norsk egenpresentasjon formet og forhandlet fram gjennom den nye utstillingsformen, verdensutstilling? Dette er spørsmål jeg vil nærme meg gjennom tre steg: først vil jeg sammenlikne en verdensutstilling av i dag med de første verdensut-

VUE GENGRALE DE L'EXPOSTTION UNIVRRSELLE

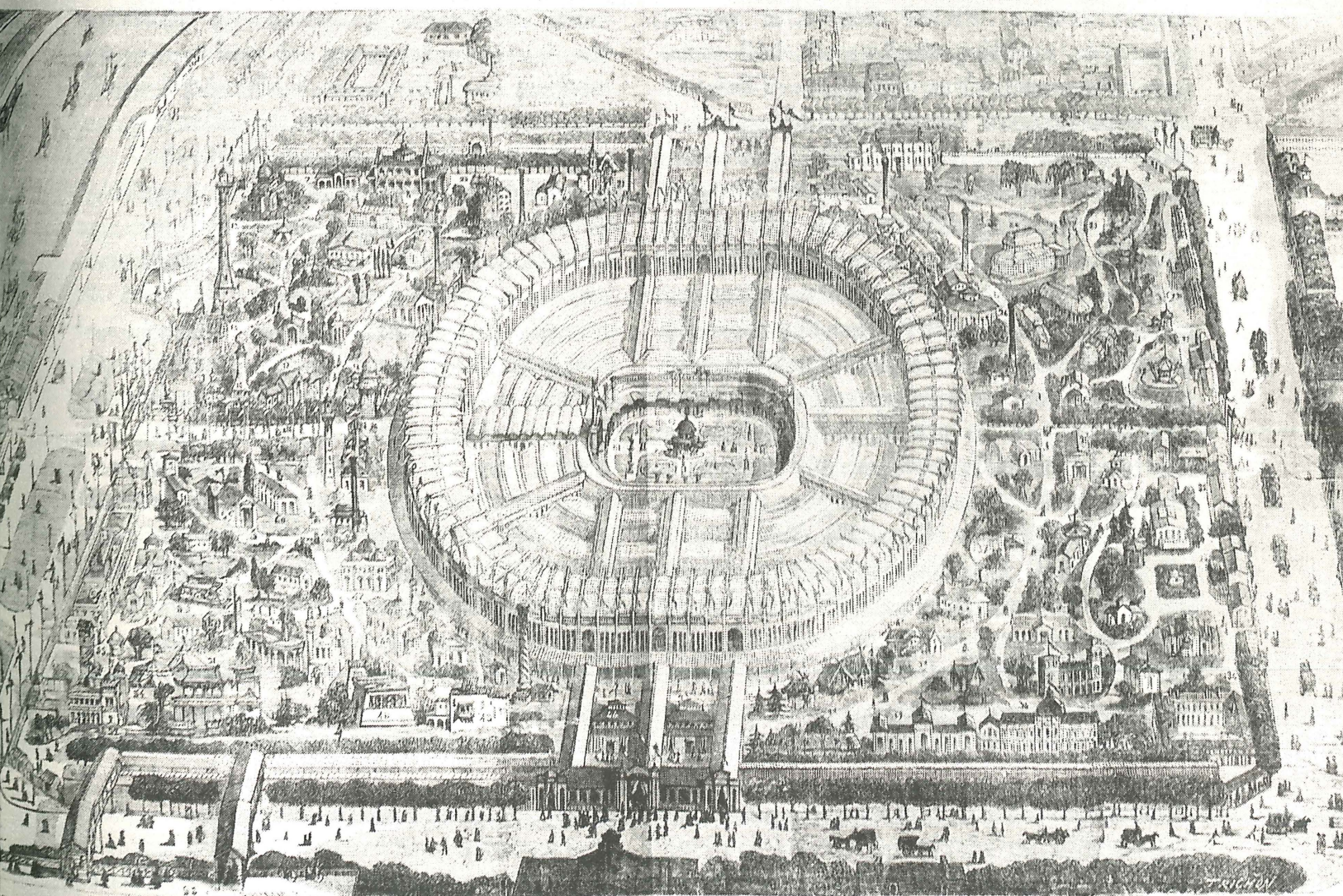


42 stillingene i forrige århundre, siden diskutere forholdet mellom verdensutstillinger og utstillingsinstitusjoner som museer, før jeg gjennomgår to ulike teorier om det moderne museums- og utstillingsvesenets framvekst, og antyder spørsmål denne gjennomgangen bringer fram i mitt norske materiale. Her ligger bakgrunnen for dette essayet, dette forsøket: jeg er på jakt etter gode perspektiver å tenke med i studiet av den norske utstillingsdeltakelsen.

\section{LISBOA: EXPO 98}

For en tid siden var jeg på verdensutstilling $\mathrm{i}$ Lisboa. EXPO 98.5 Det var en gigantisk utstilling med rundt 160 deltakende organisasjoner og nasjoner. Titusener av mennesker besøkte utstillingen hver dag, og bare den norske avdelingen hadde da jeg var der daglig omkring 6500 besøkende. Utstillingen som lå et lite stykke utenfor Lisboa sentrum var bygget på en gammel industri- og havnetomt. Den var en renlinjet, modernistisk eller kanskje postmodernistisk drømmeby; formfullendt vakker og nyskapende. Sentralt i utstillingen var en rekke store paviljonger: om utopier, om framtiden, om sjøfarernes historie, om virtuell virkelighet, og ikke minst et gigantisk akvarium. For havet vår felles arv, var utstillingens hovedtema. Det var også en rekke gigantiske haller der nasjoner og organisasjoner hadde sine egne helt atskilte avdelinger.

For meg var det nærliggende å gå gjennom utstillingen på jakt etter likheter og forskjeller mellom denne og "de gamle» utstillingene. På mange måter liknet denne utstillingen på de jeg har studert, verdensutstillingene fra 1851 til 1900 . Denne, som de gamle utstillingene var en gedigen kunstig oppbygd by, der mange av bygningene var bygget for å rives, der mye vekt var lagt på teknologi og vitenskap, og på en framheving av nasjonale særegenheter. Det var noe vemodig gammelkjent ved den - tårnet som kneiste over området, en svevende luftballong, og mennesker i enorme køer. Dette hadde jeg sett før i bildebøkene fra det forrige århundrets utstillinger. Det fantes altså mange likheter, men jeg vil trekke fram noen forskjeller mellom Lisboa-utstillingen og de gamle utstillingene som kan gi et inntrykk av hva verdensutstillingene en gang var og betydde til forskjell fra i dag.

For det første: I det forrige århundret var det et budskap og en visjon som var sterkere enn alle andre budskap på utstillingene. Menneskeheten utvikler seg, vi opplever stadig nye framskritt på alle livets områder, og disse framskrittene er en følge av teknologiens og vitenskapens stadige utvikling. Verdensutstillingene ble oppfattet og skapt som målestaver, hvor dette stadige framskrittet kunne avleses. For hver utstilling kom det nye oppfinnelser: elektrisiteten, telegrafen, telefonen, nye kjemiske fargestoffer, nye metaller, bilen, filmen, nye kunstretninger, nye moter... Selv om dette var vitenskapelige, kunstneriske eller teknologiske nyvinninger, så ble de ofte framstilt og tolket som bevis på at selve menneskeheten gikk framover. I år i Lisboa var tonen en annen. Det lyste ingen uforbeholden tro på det sosiale framskrittet fra utstillingenes tårn. En dystrere tone preget mange avdelinger: $\mathrm{Vi}$ er i ferd med å bruke opp våre ressurser, å ødelegge havet og vannet som gir oss liv, og det gjelder à redde det vi har igjen. Likevel ble det også her uttrykt optimisme på teknologiens og vitenskapens vegne: teknologi- 
en og vitenskapen ble i utstillingens ulike deler framstilt som løsninger på de økologiske problemene. Troen på det teknologiske framskrittet har altså ikke gått tapt, men det har troen på det kulturelle og det sosiale framskrittet, på Menneskehetens framskritt.

Den andre forskjellen jeg vil trekke fram har sammenheng med hvor lite vi hørte om verdensutstillingen i Lisboa i 1998. Den norske paviljongen fikk dekning i en rekke medier, i dagsrevy og TV2, i Aftenposten og løssalgsavisene. Men sammenliknet med det forrige århundrets utstillinger, der avisene hadde lange, utførlige gjennomganger av hele utstillingsområdet, der nytt fra verdensutstillingene ble slått stort opp flere ganger i uka, har oppmerksomheten vært svært liten. I 1852, etter den første verdensutstillingen i London skrev matematikeren og politikeren Ole Jacob Broch i Illustrert Nybedsblad:

Saalangt Civilisationen rækker, er der neppe en Hytte saa afsides liggende, eller et Menneske saa uvidende om, hvad der foregaaer i Verden, at han ikke har hørt Noget om Verdensskuet. ${ }^{6}$

Før TV, radio og telefon, ble utstillingenes budskap spredt svært vidt, gjennom aviser og tidsskrifter. Men Broch, som ble en ivrig forkjemper for utstillingstanken, overdrev nok deres betydning. Det var nok ikke først og fremst $\mathrm{i}$ avsidesliggende hytter, men i styrerom og departementer at verdensutstillingene hadde sine største virkninger og nådde sitt største publikum - for utstillingene var den gang en virkelig kappestrid, en beinhard internasjonal konkurranse der ekspertjuryer vurderte og delte ut medaljer til de frambringelsene de vurderte høyest innen ulike klasser. Og mange av utstillerne henvendte seg først og fremst til fagfolk og de økonomiske og intellektuelle elitene med sine varer, selv om utstillingene som helhet også henvendte seg til «lavere klasser», men først og fremst en kjøpesterk middelklasse. I dag er det menigmann som er utstillingenes viktigste publikum - i Lisboa den jevne portugiser og tilreisende turister på opplevelsesferd.

Det var også en tredje påfallende forskjell: Der det forrige århundrets utstillinger bugnet av varer var denne utstillingen stram, nøktern og ganske tom. I det forrige århundret var det ting overalt, i overveldende mengder, kunst og kunsthåndverk, maskiner av de mest ulike slag, men også store mengder av maskinproduserte varer. Allerede på den første utstillingen i Krystallpalasset (Crystal Palace) i 1851 ble det snakket om mer enn 100000 gjenstander. Mengden av ting ga bud om en overflod som alle kunne ta del i: med masseproduserte varer kunne stadig større deler av befolkningen ta del i velstandsøkningen og bli konsumenter. Disse gamle utstillingene var altså gjenstandsutstillinger. Gjenstandene ble framhevet og satt på pidestaller som budbringere: "Verdensutstillingene er valfartssteder til Fetisjen Vare,» som Walter Benjamin har sagt ${ }^{7}$ For det var gjenstandene som var bærere av utstillingenes mangslungne budskap, som hyllester til ofte ganske motstridende ideer og ideologier om nasjonalisme og fred, konkurranse og velferd, frihet og teknologiens herredømme. I Lisboa liknet utstillingen mer en moderne kunstutstilling med renskårne flater og estetisk oppsiktsvekkende arkitektur. De ulike avdelingene liknet mer på installasjoner og 
44 kunstverk enn på varemesser. Nye medier og alternative utstillingsformer preget området - ikke overfloden av ting.

Andre arenaer har også overtatt spredningen av teknologi og reklamen for varer. For eksempel har de store varemagasinene som vokste fram i utstillingenes kjølvann, nå blitt til kjøpesentra. Da trenger man ikke lenger verdensutstillinger. Og resultatet kunne man se også på menneskene som besøkte utstillingen i Lisboa: De var utrolig like. ${ }^{8}$ I skildringene av det forrige århundrets utstillinger spiller utseendet til de andre tilskuerne en stor rolle, de var nærmest en del av utstillingen. Det å se en så stor masse med mennesker på et sted, og så forskjellige mennesker når det gjaldt klesdrakt, klasse og hudfarge, det var en av de store fascinasjonene på de tidlige utstillingene. I år spilte ikke lenger de masseproduserte varene, klærne, husholdningsog pyntegjenstander en rolle som utstillingsgjenstander. Men menneskene på utstillingen kan kanskje sies å være like på grunn av dem. Organisatorene av det forrige århundrets utstillinger har nådd en av sine drømmer: varemarkedet har blitt globalt og ensartet (i alle fall som det framstår en sommerdag på utstilling $\mathrm{i}$ Lisboa).

I dag er ikke utstillingenes målsetninger lenger å stille ut alt: kanskje først og fremst fordi det finnes så mange andre kanaler for kommunikasjon mellom enkeltmennesker og mellom nasjoner, mellom fabrikanter og forbrukere og mellom folkeopplysere og opplyste folk. I dag er nytteeffekten av utstillingene i første rekke «indirekte». Nasjonene og organisasjonene som deltar gjør det for å skape et bilde - et image på godt norsk - og à gjøre et inntrykk som virker positivt. Senere vil noen kanskje besøke landet, støtte organisasjonen eller kjøpe produkter fra bedriften fordi de har gjort et positivt inntrykk. Utstillingsdeltakelsen blir PR-framstøt og ikke steder for direkte teknisk lærdom eller økonomisk nytte - kanskje mer for direkte lykke. Disse trekkene var selvsagt ikke fraværende før, men i dag er det vel disse som står igjen, når de andre effektene har fătt mindre betydning.

En siste forskjell jeg vil trekke fram gjelder Norge. Da de første utstillingene begynte $\mathrm{i}$ det forrige århundret var Norge et lite utviklet og uselvstendig land, som i utstillingssammenheng kjempet en stadig kamp, og brukte mye midler på ikke å framstå som usivilisert og kulturelt tilbakestående. I dag er Norge en av de rike nasjonene som kan, og vil, framstille seg som avansert, med høyteknologi og vitenskap, og med stor tro på sin kulturelle egenart. I Lisboa var kontrasten stor mellom de landene som tydelig hadde penger og evner til å framstå som teknologisk, kulturelt og vitenskapelig utviklede, og små fattige land som hadde innredet med turistplakater og eksotiske souvenirer.

Jeg tror noen av de forskjellene jeg har risset opp mellom årets Lisboautstilling og det forrige århundrets utstillinger peker på noen grunner til å se verdensutstillinger i lys av museumshistorie. For eksempel i forhold til tidsoppfatning: Framveksten av moderne offentlige museer forbindes ofte med en endring i tidsoppfatning. En historisk og historiserende tid slo gjennom på begynnelsen av det forrige århundret, og det var den samme lineære oppadstigende tidsoppfatningen som satte sitt preg på verdensutstillingene og på museene. ${ }^{9}$ Det folkeopplysende og folkeoppdragende element var også felles for begge: Utstillingene både ønsket å spre og spred- 
de budskapene sine svært vidt - og det samme ønsket om å nå ut til de brede massene, $\mathrm{i}$ alle fall de brede middelklassene, preget også museumsvesenet. Og i likhet med museene var innsamling og framvisning av gjenstander en hovedsak på verdensutstillingene, selv om de til forskjell fra museene var kortvarige samlinger.

\section{UTSTILLINGSHISTORIE \\ SOM MUSEUMS- ELLER MARKEDSHISTORIE}

Kildematerialet for studiet av verdensutstillingene er massivt: rapporter, kataloger, bildebøker, guidebøker, tidsskriftsartikler, avisartikler og notiser, filmer og bilder og ikke minst arkivmateriale fra utstillingskomiteer. Bakgrunnen for materialets størrelse er utstillingenes ambisjoner om å samle alt. De store utstillingene var bevisste forsøk på å samle all verdens kunnskap og materielle kultur, som sitatet jeg innleder artikkelen med viser: Det var intensjonen at den første verdensutstillingen skulle gi et sant bevis for og et levende bilde av det punktet i utviklingen hele menneskeheten hadde nådd. Ambisjonene ble ikke mindre med årene: et bredt spekter av kultur, næringsliv, vitenskap og politikk bredte seg ut på utstillingsområdene. Resultatet er, som den finske kunst- og utstillingshistorikeren Kerstin Smeds har hevdet, at verdensutstillinger kan studeres ut fra nær sagt hvilket som helst perspektiv: idéhistorisk, politisk, økonomisk-teknisk, kunsthistorisk, sosialhistorisk, arkitekturhistorisk og så videre... ${ }^{10}$ Men den ivrige og svært så ambisiøse innsamlingen som foregikk på utstillingene gjør det rimelig å se dem i tilknytning til museer.

I historiene om verdensutstillingenes opphav er det særlig to tråder som følges. Den ene er tilknytning til markedene - til den handel og det varebytte som foregikk på små og store markeder fra middelalderen av - og de store temporære utstillingene ses som forlengelser og fortsettelser av denne tradisjonen. Den andre tråden er tilknytningen til samlinger, og spesielt historien til utstillingsinstitusjoner som stilte ut for offentligheten, altså museer. Begge disse trådene trekkes med ulik styrke i bøker om de store utstillingene. Den ene understreker utstillingenes forbindelse med næringsliv og marked (i moderne forstand), mens den andre knytter an til alle de ulike former for samlinger av ting som har eksistert gjennom tidene.

Kunsthistorikeren Ingeborg Glambek har sett på forbindelsen mellom kunstindustrimuseer og verdensutstillinger (eller internasjonale industriutstillinger som de også ble kalt). Om målsetningene med industriutstillingene og de første kunstindustrimuseene, sier hun at disse «var i det hele så sammenfallende at vi med stor rett kan si at museene var permanente utstillinger og utstillingene midlertidige museer.»" Glambek viser hvordan "den kunstindustrielle bevegelse» som førte til opprettelsen av kunstindustrielle museer var et resultat av den første verdensutstillingen $\mathrm{i}$ 1851. Kunstindustrimuseene har likevel en litt annen historie enn andre typer museer - de er primært knyttet til å være forbilder for forbedring av produksjon med økonomisk gevinst som siktemål. Den koplingen Glambek viser ligger altså så og si midt mellom markeds- og samlingsargumentet - og det er antakelig et godt sted å plassere verdensutstillingene.

Det er også grunn til å se på utstillingene i tilknytning til samlings- og utstil- 
46 lingsinstitusjoner som museer generelt. For «utstilling», en hvilken som helst utstilling - det å samle kunst, dyr, varer eller maskiner for å vise dem fram for et stort anonymt publikum - var et moderne påfunn, en ny og enestående idé. ${ }^{12}$ Industriutstillingene var barn av den franske revolusjonen, og den første industriutstillingen var en del av revolusjonsfeiringen i 1798. Framveksten av andre typer utstillingsinstitusjoner - de offentlig tilgjengelige museene - var også knyttet til revolusjonen og det nye økonomiske og politiske systemet som skjøt fart i dens kjølvann. Både $\mathrm{i}$ forhold til eldre tiders samlinger hos fyrster og konger, i vitenskapelige selskaper og kirker og i forhold til markedene atskiller de offentlige museene og de store utstillingene seg ved å være laget for en ny type offentlighet - den borgerlige - og med en ny politisk funksjon i stater som legitimerte seg ved sitt forhold til folket.

Det er også tette forbindelser mellom verdensutstillinger og museal praksis. Mange museumssamlinger ble både skapt, eller i det minste supplert ved, verdensutstillinger: Det fremste eksempelet er museumsområdet rundt South Kensington i London, der landområdet ble innkjøpt og bygninger bygget ved hjelp av penger fra den første verdensutstillingen, men også starten til gjenstandssamlingen $\mathrm{i}$ det som senere ble hetende Victoria and Albert Museum ble hentet fra utstillingen. Direkte forbindelser mellom museer og verdensutstillinger kan vi finne også på andre områder enn kunstindustrien: tekniske museer, etnografiske museer, kunstmuseer, arkeologiske museer... Museumssamlinger og -fagfolk har også bidratt til utstillingsarrangementer, fra Norge deltok for eksempel allerede i 1867 Oldsakssamlingen i Paris, men mer kjent er kanskje Smithsonian Institutions medvirkning ved de gigantiske amerikanske verdensutstillingene. ${ }^{13}$ En tredje sammenheng er utstillingsteknikker, som har flytt mellom museer og utstillinger, og her er et av de mest kjente eksempelene i nordisk sammenheng forbindelseslinjene mellom utstillingen av svensk-norske bunadskledde dokker på utstillinger i Stockholm og Paris i 1866 og 1867 og den senere utstillingsformen på Nordiska Museet - panoramaene..$^{14}$

\section{MUSEUMSDEFINISJONEN}

Det verserer mange versjoner og definisjoner av begrepet museum. Et sted for samling og bevaring av den materielle kulturen, eller som en del av kulturens kollektive minne, men også et sted for levendegjøring av ting og formidling av kunnskap, eller som et sted for forskning, eller kanskje steder for nytelse og opplevelse. ${ }^{15}$ Den norske Museumsmeldingen fra 1996 definerer museer i tråd med International Council of Museums på denne måten:

Eit museum er ein ikkje-kommersiell, permanent institusjon som skal tena samfunnet og samfunnsutviklinga. Institusjonen skal vera open for publikum. Eit museum skal samla inn, bevara og sikra, forska i, formidla og stilla ut materielle vitnemål om menneska og omgjevnadene deira. Formålet er å gje høve til studiar, opplæring og oppleving (omsett og sitert frå ICOMs Statutes). ${ }^{16}$

De internasjonale utstillingene var da noe helt annet, kan man lett innvende. For det første var det aldri snakk om bevaring av den materielle kulturen, de kan nærmest 
ses på som det motsatte: steder der de nye tingene ble satt i stevne og feiret, mens de gamle forsvant ut i historiens glemsel. For det andre var disse utstillingene internasjonale - $\mathrm{i}$ motsetning til en rekke av de museene som ble bygget $\mathrm{i}$ det forrige århundret var det ikke den nasjonale kulturen, men internasjonaliseringen av samfunnet de iscenesatte. Mens den systematiske og kontrollerte innsamlingen av gjenstander etterhvert ble museenes gebet, kan verdensutstillingene ses som det motsatte, og dette er en tredje forskjell: utstillingene var mer som et ta-med-din-egenpicknick-kurv-selskap enn som en organisert middag. Det var liten plass for en konservator som styrte innsamlingen eller kurator som styrte utstillingen, fordi landene selv bestemte hva de skulle bringe. En fjerde forskjell er at museer har vært definert som steder der tingene blir trukket ut av markedets kretsløp, mens verdensutstillingenes målsetning var å bringe tingene inn i markedet. $\mathrm{Og}$ en femte er at utstillingene var underholdningsarenaer, mens museene var bærere av det store opplysende alvor.

Jeg skal ikke fortsette denne listen. Den er lang og viktig, men de motsetningene jeg har satt opp er for bastante. Den fremste forskjellen er mellom utstillingenes flyktighet og museenes varighet, mellom bevaring og markedsorientert framvisning, men likevel er det mange fellestrekk i organisasjon og funksjon. I det følgende vil jeg foreta en dannelsesreise gjennom to bøker som handler om museenes historie, Tony Bennetts The Birth of the Museum, fra 1995, og Eilean Hooper-Greenhills Museums and the Shaping of Knowledge fra 1992. Jeg vil bruke historiene om museer til å få fram problemstillinger som jeg kan ha nytte av i møtet med mitt materiale. Hensikten er å bruke disse teorihistoriene til å lage nye mønstre for fortolkning også av «mine» verdensutstillinger.

Bøkene til Hooper-Greenhill og Bennett problematiserer begge museumsbegrepet og er opptatt av hvordan et begrep om forskjell er nyttig for studiet av museer. Ingen av dem definerer museum - fordi det nettopp er de ulike betydningene det kan ha de undersøker i bøkene sine. Eilean Hooper-Greenhills bok er en undersøkelse av ulike samlingstyper opp gjennom historien, og hun ser i første rekke på ordningen og logikken i samlingene. Hennes bok begynner på 1400-tallet og henter sine case-studies fra ulike perioder fram til i dag. I hennes bok synes begrepet om museum å være knyttet til at gjenstander er samlet på en systematisk måte. Hun legger sterk vekt på at museet ikke er en essens: det finnes ikke noe egentlig museum en kan måle "museumshet» ut fra. Tony Bennett begynner langt senere, med framveksten av det moderne offentlige museet mot slutten av 1700-tallet, og han knytter denne historien mer eksplisitt til andre kulturinstitusjoner enn museer; det skal jeg komme tilbake til.

\section{FORSKJELLER,}

sier museumshistorikeren Eilean Hooper Greenhill, det er det museumshistorie bør handle om. Gjennom hele boka Museums and the Shaping of Knowledge polemiserer hun mot det hun kaller "normal historie» innenfor museumsstudier. Museumshistorie, «opp til nå», sier hun, har bestått i å ta utgangspunkt i eksisterende forhold innen museer. Dernest har disse blitt gjen- 
48 funnet så langt tilbake i tiden som mulig, og siden har man identifisert en linexr oppoverretta utvikling av disse forholdene. Museer fra tidligere tider blir slik de direkte forfedrene til dagens museer. Denne «blinde» historien, og dens mangel på analyse, forståelse og artikulasjon av dagens praksiser, har noen alvorlig konsekvenser, hevder Hooper-Greenhill. ${ }^{17}$ Jeg skal skynde meg å legge til at boka kom ut i 1992, og at hennes kritikk mot museumshistorie neppe ville vært like bastant i dag, hvor feltet for museumsstudier har blitt langt mer differensiert.

Men tilbake til hennes kritikk: For det første er det vanskelig å få med flere historier i denne "blinde» historien. Dette blir spesielt viktig for museenes historie, hvor det finnes så mange ulike former, ulike adminstrasjoner, ulike samlinger, og ulike størrelser på samlingene. ${ }^{18}$ Det andre problemet er mangelen på historisk spesifisitet. Søken etter "opphav» og "tradisjon» betyr en søking etter likheter heller enn forskjeller. De ulike politiske, kulturelle, økonomiske og ideologiske relasjonene som karakteriserer de forskjellige museums- og samlingsstypene blir gjort usynlige. ${ }^{19}$ For det tredje er det vanskelig å artikulere begreper om endring. Hvis formålet er å vise hvordan ting har forblitt de samme, hvordan forstår man da endring? Og ser man ikke muligheten for endring for museene, da blir man også fastlåst i fortiden når man skal forstå nåtidens museer. ${ }^{20}$

I denne kritikken av museumshistorier har hun også lagt ut en del av forutsetningene for sin egen analyse. Michel Foucault er hennes rammeverk å forstå museumshistorien innenfor. Det gjelder særlig Foucaults bøker Vitensarkeologien og Ordene og tingene. Hun bruker hans begreper, teorier og analyser i stor grad gjennom hele boka.

Det hun først og fremst vektlegger er museene som kunnskapsinstitusjoner. «Kunnskap er varen museene tilbyr,» sier hun, «men hvis museer er steder der vi kan få vite nye ting, og hvor oppfattelsen vår av verden kan endres radikalt, hvilken karakter har så denne kunnskapen, og hvordan skjer denne endringen? ${ }^{21}$ Svaret henter hun i Foucaults begrep om episteme som hun definerer som det ubevisste, men positive og produktive settet av relasjoner hvor kunnskap produseres og rasjonalitet defineres. Historikeren Erling Sandmo har gitt en litt klarere definisjon av episteme:

Et episteme er et historisk avgrenset tankesystem, en slags kulturell matrise som gir mening til en tids og en kulturs viten, tenkning og praksis. En kan kanskje si at et episteme er en slags kunnskapsteoretisk tidsånd, det er det store og abstrakte settet av mekanismer som gir struktur til det man sier, vet og gjør. ${ }^{22}$

Det finnes en rekke diskurser innenfor hvert episteme, ulike kunnskaps- eller vitensfelt der det produseres mening. Men disse diskursene er aldri enhetlige eller handler om én ting, de overlapper og forskyver hverandre, og åpner derfor for en konstant produksjon av nye betydninger og av endring. ${ }^{23}$

Foucault opererte med tre hovedepistemer, som Hooper-Greenhill tar utgangspunkt i og bruker som mal i resten av boka: renessansens episteme, det klassiske og det moderne epistemet. Hennes historiske analyse av museer er først og fremst en analyse av ulike typer rasjonaliteter som ligger i forskjellige samlinger. Bruddene mellom epistemene betydde en 
fullstendig nyskriving av kunnskap, hevder hun med Foucault. Hun ser museet som et sted som har vært involvert i konstruksjonen av ulike rasjonaliteter, og plasserer case-studiene sine i skjæringspunkt og i bruddflater mellom de ulike epistemene for å få grep om samlingenes eller museenes delaktighet i konstruksjonen av nye rasjonaliteter.

Hva skal hun så med denne teoretiske vinklingen? Hooper-Greenhill tar i boka for seg en rekke enkeltstudier. Først Medicipalasset i Firenze i perioden 14501500 , som hun ser i lys av at renessansens episteme innledes her. Her finner hun begynnelsen til en ny type samling, som var forskjellig fra middelalderens og innebar en ny rasjonalitet. Samtidig identifiserer hun elementer som stammer fra middelalderen. Dernest tar hun for seg ulike versjoner av kunstkamre, kuriositetskabinetter og kunstskap, eller 'verdenskabinetter' som er navnet hun velger å forene dem under. I disse ser hun en mer fullstendig versjon av renessanse-epistemet. Det klassiske epistemet eksemplifiserer hun med samlingen til the Royal Society i London, og det samtidige forsøket på å etablere et universelt språk. Det siste eksempelet henter hun i skjæringspunktet mellom det klassiske og det moderne epistemet: Framveksten av det offentlige museet i kjølvannet av den franske revolusjonen. Dette ser hun som gjennombruddet for det moderne "disiplinære» museet, som hun kaller det.

Klassifikasjonen på museer har funnet sted innen en selvfølgelighets-etos, sier Hooper-Greenhill. Utvelgelsen og ordningen ses sjelden som historisk og geografisk spesifikk, bortsett fra på en veldig rudimentær måte. På samme måte er gjen- standene tatt for gitt. Konstruksjonen av materielle ting som 'objekter av en bestemt type' oppfattes ikke som problematisk. Ting er det de er, og man legger ikke vekt på at ting kan ha forskjellige betydninger og kan forstås på ulike måter. Og man ser heller ikke på hvordan ordningen av tingene henger sammen med oppdelingen av rom og ordningen av individer. Dette er altså de fire hovedelementene hun unsersøker de ulike samlingstypene etter: den bakenforliggende rasjonaliteten som uttrykkes spesielt i klassifikasjonen, objektenes skiftende betydning, subjektenes skiftende posisjoner og de ulike oppdelingene av rommet.

Hva slags spørsmålsstillinger kan jeg hente ut av Hooper-Greenhills museumshistoriske gjennomgang? Hvordan kan hun hjelpe meg til å forstå verdensutstillingene, og den norske deltakelsen, ikke som naturgitt og en selvfølgelig, men som noe som må forklares i forhold til andre måter å arrangere ting på? Og, hvordan atskiller verdensutstillingenes ordninger seg fra de hun beskriver for museenes utvikling?

\section{KLASSIFIKASJON}

Hooper-Greenhill legger mye vekt på hvordan tingene ordnes, hvordan tingene får mening $\mathrm{i}$ forhold til helheten av samlingene. I bøker om verdensutstillinger trekkes det som tidligere nevnt ofte tråder fra de store markedene fra middelalderen av og fram mot de internasjonale utstillingene. Men denne tråden ser bort fra ett av de helt sentrale ordningskriteriene ved utstillingene: klassifikasjonen. På verdensutstillingene var klassifikasjonssystemene det fremste ordningskriteriet. "Klassifika- 
50 sjonen er utstillingens bibel,» het det i en utstillingsbok som kom ut i 1921: "Den forteller hvilke utstillingsgjenstander som skal stilles ut, og i hvilken orden. Den gir dem deres plass i livets skjema, og bestemmer måten å gi belønninger på. ${ }^{24}$ Livets skjema bestemmer altså hvordan gjenstandene skal plasseres på en verdensutstilling, tingene ordnes og gis betydning innen en struktur med livet selv som målestokk. Belønningene er et annet moment sitatet trekker fram, og dette konkurranseelement atskiller klart utstillingene fra de permanente utstillingsinstitusjonene. Sammensetningen mellom livets skjema og belønninger, er også viktig: Verdensutstillingene framstår i dette sitatet som en konkurranse med livets skjema som målestokk, og det må bety noe i retning av at det er menneskehetens utvikling og tilstand som måles på utstillingene. Men, mer konkret hvilke funksjoner var det klassifikasjonen skulle fylle?

I innledningen til den lille boka som beskriver klassifikasjonssystemet for utstillingen i 1855, står det en oversikt over hva som skal være hensikten med klassifikasjonen: Målene er flere, heter det, for det første å bestemme en generell ordning for plasseringen av produktene i utstillingens bygninger. For det andre å presentere objektene i henhold til en logisk metode for å lette arbeidet til juryene i de ulike klassene. For det tredje å gjøre kjent for utstillerne på forhånd hvilken plass deres produkter skulle innta i helheten. For det fjerde å veilede de franske og utenlandske komiteene som er ansvarlige for utvelgelsen av produktene. ${ }^{25}$

Plassering, vurdering og utvelgelse av produkter - det var altså klassifikasjonens uttalte funksjon, noe som viser hvor sen- tral klassifikasjonen var. Den ble også aktivt brukt - når Norge mottok innbydelser til utstillingen, fikk de også etter hvert foreløpige utkast til klassifikasjonen, og den ble sendt ut som et hjelpemiddel for de som ville melde seg på til utstillingsdeltakelse. Innskriving av gjenstander i utstillingenes kataloger baserte seg også på forhåndsopplysninger om tingene og $\mathrm{i}$ hvilke klasser de hørte hjemme. Norske deltakere fylte selv ut skjemaer når de meldte seg på hvor de beskrev gjenstandene. Men hvilken rasjonalitet var det denne klassifikasjonen uttrykte? for å holde oss til Hooper-Greenhills språkbruk. Hva var den bærende rasjonaliteten i klassifikasjonssystemene?

Prinsgemalen Albert var en av de førende skikkelser ved den første verdensutstillingen i London i 1851. Han var dens beskytter, men han tok også aktivt del i planleggingen. Han foreslo for Krystallpalass-utstillingen et system som var talende enkelt. Tre hovedkategorier tenkte han seg: Industriens råvarer; produktene laget av dem og kunsten som ble brukt til å utsmykke dem. Begrunnelsen var at vitenskapen oppdager lovene for kraft, bevegelse og endring, industrien anvender dem på råmaterialet, som jorden gir oss i overflod, men som blir verdifull bare ved kunnskap; kunsten lærer oss de uforanderlige lovene for skjønnhet og symmetri, og gir våre produkter form $\mathrm{i}$ samsvar med dem. ${ }^{26}$ Alt med Alberts ord. Alberts skjema møtte motstand, fordi det manglet "common sense», og et alternativt forslag ble lagt fram av kjemikeren Lyon Playfair. I dette systemet ble det skilt mellom ulike produksjonsprosesser, og Playfairs ønske var å finne et system der ulike ekspertgrupper kunne knyttes til ulike produkt- 
grupper. For Playfair var det avgjørende at skjemaet kunne anvendes som et instrument for ordning og sammenlikning, og han la mindre vekt på at systemet skulle vise til hvordan verden egentlig var. Men i siste instans ble prinsens skjema beholdt, men inndelt i 30 klasser med fire hovedgrupper. Det ble i første omgang planlagt bare å stille ut tingene ut fra hvilke klasser de tilhørte og ikke ut fra nasjonalitet, men dette ble oppgitt av praktiske grunner på et tidlig tidspunkt. ${ }^{27}$ Fred, frihet og frihandel var de ideologiske honnørordene for denne utstillingen: men åpningen for det nasjonal konkurranse underminerte, eller ga $i$ alle fall en ny vending til innholdet $i$ disse begrepene, og for den videre utviklingen av klassifikasjonen på verdensutstillingene kom dette til å ha stor betydning.

I prinsens skjema ser vi hvordan en rå natur blir verdifull for mennesket bare ved dets kunnskap, og dets arbeid, industrien. Lovene for skjønnhet og symmetri er uforanderlige, og skal styre utsmykningen av våre produkter. Men tema og logikken bak utstillingen utkrystalliserer seg som et sted der menneskets arbeid står i sentrum: Det er menneskets aktiviteter, dets industri som skaper verdier, og produkter som er verdt å utstille. ${ }^{28}$ Til forskjell fra de tidlige samlingene var ikke sentrum ett bestemt menneske, eller Gud, det var det arbeidende mennesket som et abstrakt prinsipp som var målestaven. Tingene ble ordnet ut fra likheter og forskjeller, men også ut fra det bakenforliggende arbeidet, produksjonen. Klassifikasjonen ble derfor tredimensjonal på en måte som ikke den klassiske samlingstypen hadde vært, de viste til et underliggende dynamisk prinsipp, arbeidet. Mennesket og dets driftighet blir altså det sammenbindende elementet i utstil- lingen, midtpunktet som tingene ordnes i forhold til. Dette samsvarer også med Hooper-Greenhills syn på ordningen av moderne samlinger:

I den moderne tidsalder blir ikke kunnskapen lenger formet av de hemmelige, lukkede, sirkulerende strukturene til renessanseepistemet; heller ikke av de flate, klassifiserende tabellene for forskjeller i det klassiske epistemet; nå struktureres kunnskapen gjennom en tre-dimensjonal, holistisk erfaring som defineres gjennom forholdet til mennesker. ${ }^{29}$

Systemet for klassifikasjon som ble utprøvd på den første verdensutstillingen ble utvidet og modifisert etterhvert, men det er vanskelig å få øye på noen store forskjeller. De gjaldt først og fremst rekkefølgen til kategoriene og tilføyelser av nye grupper og klasser. Det mest ambisiøse forsøket på å tilføye noe nytt til systemet kom med utstillingen i Paris i 1867: Her var siktemålet uttalt å lage en tredimensjonal encyklopedi. Det spesielle med denne utstillingen var at også utstillingsstrukturen helt og holdent ble bestemt av klassifikasjonssystemet. Klassifikasjonen ble delt inn i 10 hovedgrupper og 95 klasser, en drastisk økning fra den første utstillingen i $1851 .^{30}$

I dette systemet fikk kunsten førsteplass og de videre klassene viser hvordan systemet er satt opp etter menneskets behov. Men det er litt spesielt menneske: I midten av utstillingsstrukturen lå en tempelliknende bygning som rommet en utstilling av alle verdens vekt, mål og myntsorter, og samtidig med utstillingen foregikk det en diskusjon om etableringen av felles mål, vekt og myntstandarder. ${ }^{31}$ I ovalen som omkranset tempelet var den innerste viet «arbeidets historie»: en historisk framvisning av menneskenes arbeid gjennom 
52 tidene. Deretter fulgte de ulike gruppene utover i utstillingspalassets ovaler. Helt sentralt lå slik mål-, vekt- og myntenheter, omkranset av historien til det arbeidende mennesket, homo faber, og deretter dets produkter. Det var slik et bestemt menneske, det økonomisk handlende og praktisk arbeidende, som hadde blitt universets midtpunkt.

\section{NORGE KLASSIFISERT}

Et annet aspekt ved dette systemet hadde kanskje større betydning for den norske deltakelsen. Utstillingen innførte og gjennomførte prinsippet om at gjenstander skulle plasseres og sammenliknes både etter gjenstandstype og etter nasjonalitet. Nasjonene ble plassert langs akser ut fra utstillingsparken i midten - derfor hadde alle land 163 meter å fylle, men i ulik bredde - «etter deres Rang som Nationer» - som det het. Dette bød på problemer for små land:

Denne Opstilling af Sagerne danner en af den franske Udstillings Grundprinciper, som man ikke i nogen væsentlig Grad har kunnet fravige, ligesom det heller ikke er skeet af noget andet Land. For den norske Udstilling har denne Forskrift ikke været gunstig, da den har medført at den Plads, som kunde benyttes til Udstillingsgjenstande vedkommende vore vigtigste Næringsveie Fiskerierne, Skibsfarten, Trælasten, Bjergværkerne samt til Maskiner m.m., er bleven betydelig indskrænket, medens der ikke paa langt nær var anmeldt tilstrækkeligt af Sager til at fylde de Afdelinger, som er forbeholdt Industrigrene, hvori vort Land kun har Lidet at Opvise. Dette gjælder navnlig de i Midten af vor Udstilling beliggende Afdelinger for Material henhørende til de fire Kunster, for Luxusmøbler m.v. og for Beklædningsstoffe. ${ }^{32}$
Der hvor de store nasjonene hadde en jevn fordeling av varer, kunne ikke de små landene oppvise samme mangfold.

Utgangspunktet for klassifikasjonssystemene var altså hva store land, og som regel vertslandet hadde å vise fram. Klassifikasjonene forutsatte altså ikke bare en tredimensjonal oppdeling. Utstillingens oppdeling skapte eksplisitt et hierarki - hvor landene ble plassert på en stige fra usivilisert til sivilisert - gjennom hvordan de fylte opp ulike avdelinger, og gjennom hvordan de ble plassert i palasset etter deres rang som nasjoner. Klassifikasjonssystemene synes å ha gitt budskaper om hva et «sivilisert» land burde kunne stille opp med for å regne seg blant de siviliserte. ${ }^{33}$ De norske katalogene som ofte ble utarbeidet på vertslandets språk, med oversikt over norske produkter, var også basert på utstillingenes klassifikasjoner. Slik ble representasjonen av det norske framstilt gjennom tilstedeværelsen i de ulike kategoriene. Klassifikasjonssystemenes oppdeling og logikk hadde funksjon som et mønster som alle de deltakende landene inkorporerte som en norm i framstillingen av seg selv. Tingenes orden på verdensutstillingene, og det verdenssyn som dette innebar, fikk derfor en anvisende funksjon i forhold til andre land. På de nasjonale norske industriutstillingene ble også klassifikasjonsmåtene fra utlandet hentet inn som et forbilde. ${ }^{34}$

\section{SUBJEKTPOSISJONER}

Hvis jeg henter opp igjen HooperGreenhills terminologi gir det utgangspunkt for å se hvordan subjektposisjoner konstrueres i tilknytning til klassifikasjonssystemene og utstillingenes orden. 
For eksempel dannes på basis av hva et land kan vise til i de enkelte klasser kollektive subjektposisjoner. Nasjonen framstår som et enhetlig subjekt - her Norge på verdensutstilling - og dette konstrueres i samspill med og i utstrakt grad ved hjelp av «spillereglene» på utstillingsfeltet. Nasjonen framsto som et kollektivt subjekt, som en aggregering av befolkningens totale industri.

Det ble gitt rom for en rekke andre subjektposisjoner. For det første det anonyme publikum, en posisjon som var felles for samtidens museer, men også for det nye urbane bylivet - det er på denne tiden flanøren begynner å botanisere på asfalten. Men denne posisjonen var annerledes på utstillingen enn i byen - den tillot i større grad også kvinner å innta det offentlige rommet. For det andre var det en posisjon som utstillingsadministrator og organisator, en posisjon som ga helt nye erfaringer for deltakere i lokale og nasjonale komiteer i Norge, men også for de som var tilstede på utstillingene og knyttet internasjonale kontakter. For det tredje oppsto en posisjon som utstiller, som også var tilgjengelig på nasjonale utstillinger, denne ga helt nye grupper muligheten til å bli representerte $\mathrm{i}$ offentlige sammenhenger. Den ga også en rekke enkeltmennesker og deres gjenstander muligheter for å framstå som representanter for nasjonen. For det fjerde ser vi også en posisjon som ekspert som behersker klart avgrensede felt, og med mulighet til å bedømme og vurdere i samarbeid med andre som representerte det samme fagfeltet. Stadig flere jurymedlemmer fra Norge kunne innta denne posisjonen.

De mange ulike subjektposisjonene som ble skapt på utstillingene viser forskjellen på museenes og de internasjonale utstillingenes virkninger. Det moderne «disiplinære» museet som det vokste fram fra slutten av 1700-tallet analyseres i HooperGreenhills bok som et sted der det vokste fram to klart atskilte subjektposisjoner, eksperten som arbeidet i de skjulte systemene i museet, som hadde kunnskap og tilgang til museets private deler, og på den andre siden den passive publikummer som bare hadde tilgang til museets offentlige avdelinger. ${ }^{35}$ På verdensutstillingene var disse grensene langt mindre tydelige, rommene var ikke så klart atskilt mellom "offentlig" og "privat», og det var også åpent for en rekke andre subjektposisjoner.

\section{DISIPLINENES MUSEER OG UTSTILLINGER}

Hooper-Greenhills museumshistorie legger størst vekt på førmoderne samlinger. Tony Bennett legger $\mathrm{i}$ The Birth of the Museum derimot utelukkende vekt på framveksten av det offentlige museet som vokser fram fra slutten av 1700-tallet. Han er opptatt av å se museene, ikke bare i tilknytning til tidligere samlingspraksiser, men til en rekke andre kulturelle institusjoner, og han kritiserer HooperGreenhill for å se på forhold som er interne for museet. ${ }^{36}$ Han knytter museer, internasjonale utstillinger og fornøyelsesparker sammen. Dette begrunner han med at for det første er disse institusjonene involvert $\mathrm{i}$ "showing and telling»: dvs. i å vise fram artefakter eller mennesker på en måte som innebærer og kommuniserer spesifikke kulturelle betydninger. For det andre er dette institusjoner som er åpne for alle, og for alle tre institusjonstypene 
54 har det vært viktig å regulere oppførselen til den besøkende. De ønsker å gjøre dette på måter som ikke er påtrengende og aller helst virker av seg selv. For det tredje så er de besøkendes opplevelser avhengig av at de forflytter seg selv, de er "minds on legs», og de skal forflytte seg organisert omkring, for at budskapet skal oppfattes. ${ }^{37}$

Som vi ser er Bennett i denne framstillingen nesten utelukkende opptatt av utstillingenes og museenes funksjon i samfunnet som budskapsformidlere, og som regulerende instanser for menneskene. Museer, utstillinger og fornøyelsesparker er for han kulturelle teknologier for regulering av befolkningen og formidlere av bestemte budskap. Museenes og utstillingenes rolle som bevarere av den kollektive hukommelsen, eller som steder der materialitetens mening utforskes, eller som samlings- og oppbevaringssteder, er sterkt nedtonet.

\section{«UTSTILLINGSKOMPLEKSET»}

er et begrep Bennett utvikler i artikkelen med samme navn i boka The Birth of the Museum. Han innleder med a forklare hva man kan tenke seg ligger innenfor det han kaller utstillingskomplekset. Det er institusjoner som historiske og naturvitenskapelige museer, dioramaer og panoramaer, nasjonale og internasjonale utstillinger, arkader og stormagasiner. Dette var steder der nye disipliner som historie, biologi, kunsthistorie og antropologi ble utviklet og sirkulerte. Det gjorde også det Bennett kaller diskursive formasjoner, det vil si nye begreper om verden som fortiden, evolusjon, estetikk, mennesket. I disse institusjonene ble det også utviklet nye synsteknologier, nye måter å se og erfare på.
Dette var artikulasjoner av makt og kunnskap, sier Bennett. Altså steder der makt og kunnskap virket sammen. Men, sier han, de var basert på motsatte strategier av dem Foucault analyserte i Fengselets historie. Han snakket om innesperring, mens dette var institusjoner for utstilling. Foucault analyserte hvordan makt gikk fra å være offentlig utstilt til å bli avsondret fra offentlighetens påsyn, mens det motsatte skjedde i utstillingskomplekset. Utstillingsinstitusjonene flyttet gjenstander og kropper som før bare et fătall hadde hatt tilgang til, ut i det offentlige rommet. Denne prosessen gikk parallelt med den «innesperringsprosessen» Foucault analyserte, sier Bennett.

Foucault vurderte åpningen av det nye fengselet i Mettray i 1840 som et privilegert øyeblikk, hvor alle de ulike disiplineringsstrategiene ble samlet innen en struktur. Bennett ser Krystallpalasset som et motsvar til dette, hvor en helhet av utstillingsdisipliner og -teknikker ble brakt sammen: fra museer, panoramaer, Mechanic's Institute utstillinger, kunstgallerier og arkader..$^{38}$

I Krystallpalasset ble gjenstandene ordnet for offentlig inspeksjon. Men samtidig ordnet det publikummet som inspiserte. På samme måte som straffesystemet var utstillingskomplekset et svar på behovet for orden, men det virket forskjellig, hevder Bennett. Utstillingskomplekset søkte å endre ordensproblemet til et kulturproblem, et spørsmål om å vinne hjerter og sjeler så vel som å disiplinere og trene kropper. ${ }^{39}$ I utstillingskomplekset søkte man å gi menneskene mulighet til å vite, heller enn å bli visst om, til å bli kunnskapens subjekter, heller enn kunnskapens objekter. Det var steder hvor menneskene 
skulle internalisere maktens blikk gjennom selv-overvåkning og selv-regulering. ${ }^{40}$

Utstillinger og museer var del av en prosess der det å lage «spectacles», skuer eller forestillinger, for et stort anonymt publikum ble stadig mer utbredt. Her er det flere tendenser, sier Bennett: Først er det tendensen til at samfunnet blir framstilt som et skue eller en forestilling. En rekke tiltak ble gjort for å åpne samfunnet for innsyn, lage lange rette gater, bygge utkikkssteder, åpne stadig flere steder for inspeksjon, samle inn opplysninger om alt og alle og framstille det grafisk eller i tabeller. For det andre var staten stadig mer involvert i slike bestrebelser. Og for det tredje, med utstillingskomplekset, med museene og utstillingene og de andre institusjonene, ble slike utstillinger av makten permanente. ${ }^{41}$

Institusjoner som permanente museer og store utstillinger var steder hvor befolkningen kunne lære siviliserthet. Det var også steder hvor de kunne lære å identifisere seg med makten:

$\AA$ identifisere seg med makten, å se den om ikke akkurat direkte som deres, så $\mathrm{i}$ alle fall indirekte som en kraft som ble regulert og kanalisert gjennom samfunnets styrende grupper til alles beste: Dette var maktens retorikk materialisert i utstillingskomplekset - en makt gjort konkret, ikke i egenskap av smertepåfører, men i egenskap av å kunne organisere og koordinere en tingenes orden og til å produsere et sted for menneskene $\mathrm{i}$ relasjon til den ordenen. ${ }^{42}$

Gramscis begrep om stat og det sivile samfunn blir av Bennett brukt til å «komplimentere» Foucaults analyse. Der Foucault, ifølge Bennett, gjennom fengselet bare så statens tvangsmakt, var utstillingene et eksempel på det sivile samfunnets overtalelseskraft. Hvis museet og botsfengselet representerte maktens Janus-ansikter, så var det $\mathrm{i}$ det minste en symbolsk ytelsesfordeling mellom dem, sier han. For de som ikke ble vunnet over på maktens side ved hjelp av museer og skoler, var fengselets murer en alternativ instruksjonsmåte. ${ }^{43}$

På verdensutstillinger og museer ble man oppmuntret til å identifisere seg med makten. Her ble maskineri og industrielle prosesser, ferdigvarer og kunstobjekter, forvandlet til materielle signifikanter for framskrittet - et framskritt der kapitalen var den store ko-ordinatoren. En av teknikkene var å understreke skillet mellom de siviliserte og de usiviliserte, å overbevise tilskueren om at han var på de sivilisertes side, og dermed gjør han til en del av makten. ${ }^{44}$

Hva var så logikken bak dette behovet for kontroll, for kulturelle teknologier som sørget for at befolkningen ble sine egne overvåkere? Svaret er ganske enkelt eneveldenes fall. Nar herskerne ble folkets tjenere, når de var avhengige av folkets velvilje for å regjere, da måtte folket disiplineres til å velge herskerne. Tidligere samlinger under de mest ulike navn; museer, studioli, kuriositetskabinetter, Wunderkammer og Kunstkammer hadde fylt en rekke funksjoner, sier Bennett, men de delte to prinsipper: De var privat eiet og tilgangen var begrenset. Utstillingskomplekset brøt med begge prinsippene: samlingene ble offentlig eiet, administrert av staten til beste for et bredt publikum. Og det var her betydningen av utstillingskomplekset kom inn, det ga muligheter for nye instrumenter for moralsk og kulturell kontroll av de arbeidende klassene. ${ }^{45}$ 
56 Men museer var mindre fleksible enn store utstillinger: Der museenes budskap var vanskelig å endre, kunne utstillingenes budskap tilpasses spesifikke hegemoniske strategier hos ulike nasjonale borgerskap ettersom de endret seg over tid. Utstillingene gjorde tingenes orden dynamisk, og mobiliserte strategisk i forhold til de mer kortsiktige ideologiske og politiske krav i øyeblikket. ${ }^{46}$

\section{NORGE OG UTSTILLINGS- KOMPLEKSET}

I sin utlegning understreker Bennett den individuelle disiplineringen - eller siviliseringen. Han vektlegger staten, men først og fremst statens disiplinering av den egne befolkningen. For denne befolkningen etablerer han utstillingskomplekset som et jernbur som de ikke kan komme ut av de blir overvåket, overvåkningen blir internalisert, og de blir selv overvåkere. Den logiske kritikken av hans posisjon er å spørre om folk faktisk gjorde som de ble fortalt, opplevde det organisatorene ville de skulle oppleve, osv. Denne kritikken har han tatt høyde for $\mathrm{i}$ innledningen til boka si, og sier at han bare har sett på planer og prosjekter, ikke på hvordan museer, utstillinger, og fornøyelsesparker faktisk ble oppfattet av publikum. ${ }^{47}$ Det gir likevel boka en litt begrenset bruksverdi, fordi bokas retoriske kraft ligger $\mathrm{i}$ at den hele tiden henter inn eksempler på at utstillingskomplekset virket nærmest utelukkende disiplinerende.

For meg ligger en av de vesentligste bidragene $\mathrm{i}$ boka $\mathrm{i}$ hans påvisninger av hvordan det var et utstrakt samspill i funksjonsmåte for museer og store utstillinger. Han viser og understreker betyd- ningen av å se på kulturinstitusjoner som "politiske teknologier", og betydningen av à se ulike kulturinstitusjoner i sammenheng. Bennett legger også vekt på statens rolle. Som jeg nevnte innledningsvis var interessen og bidragene fra den norske staten betydelige. Noe som kan forklares ut fra viljen til å markere selvstendighet overfor Sverige, men noe av logikken i den sterke vekten på deltakelse kan også stamme fra utstillingsfeltet. For utstillingskomplekset kan også ses som en disiplinering av stater. Det kollektive subjektet Norge som ble skapt på utstillingsarenaen ble overtalt til å være en del av makten, se seg selv på maktens side. Som en av de siviliserte nasjonene. "Disse Ting [Verdensutstillingene] har faaet den Betydning, at det Folk, der holder sig borte derfra, burde med det Samme skrive sig ud af Listen over de civiliserede Folkefærd," het det i Stortingsbehandlingen av den norske deltakelse på utstillingen i Paris i $1867 . .^{48} \mathrm{Og}$ dette var argumenter som stadig gikk igjen. Det gjaldt å skrive seg inn i den hierarkiske ordningen av nasjoner fra usivilisert til sivilisert på det riktige stedet. Det gjaldt å skrive seg inn på de mektiges side.

Den statlige deltakelsen fra Norge begrenset seg ikke til økonomisk støtte. Allerede på den første utstillingen i 1851 deltok Kongsberg Sølvverk ikke på eget initiativ, men fordi departementet hadde overtalt dem til det. Men statlige organer deltok i større og større grad som representanter, dette kan man for eksempel lese ut av premielista for utstillingen i Paris i 1878. Da fikk Kirkedepartementet gullmedalje for Skolemateriel for Almueskolen, Den geologiske Undersøgelse af det sydelige Norge for en samling mineralier og Bergarter, Landbrugsdirektøren for 
Karter over Landbrugets Udvikling i Norge, Direktøren for Justervæsenet for en Samling af norsk metrisk Maal og Vægt, Medicinal-Direktøren for Statistiske Arbeider over Sundhedstilstanden i Norge og Kunstindustrimuseet fikk medaljer av ulike slag for sølvarbeider og broderte og vevde arbeider. ${ }^{49}$ Dette er bare noen eksempler fra en utstilling, men det de viser er den utstrakte viljen fra statlige organers side til å skrive seg inn $\mathrm{i}$ «utstillingskomplekset». Dette var en måte å bli selvstendig subjekt på, men som kollektivt subjekt var det formet, underkastet utstillingens logikk, og dette var igjen et blikk som var internalisert som selv-overvåkning og selv-kontroll.

På den andre siden virket ikke utstillingene disiplinerende overfor den norske befolkning på samme måte som de gjorde i de store nasjonene. Bennetts påvisninger av hvordan skiftende hegemoniske grupperinger brukte utstillinger i sine politiske kamper har ikke samme forklaringskraft i Norge. Først og fremst fordi de millioner av mennesker - fra seks millioner i 1851 til femti millioner i Paris i 1900 - som så de store utstillingene i første rekke var fra vertsnasjonen selv. For det andre var de utstillingsorganiserende nasjonene imperialiststater med klare ønskemål om å få befolkningen til å ha en følelse av enhet og samhold, og en rettferdiggjøring av å bruke penger og soldaters liv på å opprettholde de oversjøiske koloniene. Effekten på den norske befolkningen var avgjort mer marginal, og effekten må også forstås i forhold til at den norske nasjonsbyggingsprosessen bygget på andre forutsetninger.

\section{EN FORELØPIG KONKLUSJON}

Hvordan kan jeg forstå norsk utstillingsdeltakelse i lys av museenes historie har jeg spurt. Og det er flere svar: Et fokus på samlinger og museer kan gi meg forståelse av de underliggende ordningskriteriene på utstillingsfeltene, og hvordan dette igjen skapte ulike rom for de norske deltakerne. Det kan også gi meg innspill til å forstå utstillingsdeltakelsen i forhold til det liberale gjennomslaget i politikken på 1800 tallet, og se på utstillingenes funksjoner i forhold til statsmakten. De studiene jeg har sett på understreker også betydningen av å lese utstillingsdeltakelsen opp mot museumsoppbyggingen i Norge, for å finne gjensidige møtepunkter. For det å delta på en verdensutstilling var ikke en selvfølge - en utstilling var $\mathrm{i}$ seg selv ingen selvfølge - utstillingene innebar en utvikling av et spesifikt sett av teknikker for representasjon eller måter å ordne verden på som deltakerne måtte tilpasse seg, men som de samtidig var med på å forandre og utvikle.

Det er likevel verken mulig eller ønskelig å lese den norske utstillingsdeltakelsen direkte inn i de makrohistoriene jeg har presentert om museer og utstillingers historie. Men det de gjør er å trekke blikket mot det som helt konkret skjer i det ting stilles ut for et publikum. Derfor gir Hooper-Greenhill og Bennett et godt inngangspunkt for å studere i detalj hvordan objekter stilles opp, hvilke som står ved siden av hverandre, hvor publikummet står i forhold til objektene etc. Dette er spørsmål jeg burde kunne kommet på selv. Men Hooper-Greenhill og Bennetts styrke ligger i måten de kombinerer øyet for de små detaljene med «samfunnsmessige 
58 strukturer», med «kulturen» eller hva vi nå skal kalle dette mangehodete uhyret. De får til dette ved å vise fram det fremmede og nye i utstillings- og museumshistorien på 1800-tallet. Og de lager spennende forbindelseslinjer mellom kunnskapens, kroppenes, tingenes og maktens historie.

\section{SUMMARY}

A true and vivid picture of the world; world exhibitions and museum history

Norwegian participation in International Exhibitions, World Fairs and Expositions Universelles in the last century and its potential relationship to museum history is the subject of this paper. It starts with a juxtaposition of EXPO'98 in Lisbon and the international exhibitions that were arranged in the last century. The juxtaposition highlights how the cultural effects of ideas are transmitted by international exhibitions and how the rationale for such events has changed since the 19 th century. This comparison serves as a background for a discussion of the exhibitions of the last century in museological terms. It is argued that there are good reasons for a comparison and for viewing the international exhibitions in the light of the development of museums and museum practice.

Works by Eilean Hooper-Greenhill and Tony Bennett are used to raise new questions and bring perspectives to the study of the Norwegian participation in the exhibitions. How can their theories be used to discern new features in this participation? The paper presents some of the main arguments in Hooper-Greenhill's book Museum and the Shaping of Knowledge and Tony Bennett's The Birth of the Museum. History, Theory, Politics.

The classification systems applied in the world exhibitions and the importance of these systems for a country like Norway are discussed with the aid of Hooper-Greenhill's concepts for analysing the forming of museums. Studying different collections she emphasises four elements: the rationality expressed mainly in the classification, the differing meanings of the objects, the shifting position of the subjects, and the various orderings of space. The classification systems are seen as vehicles for expressing rationalities, that confer meaning on objects, allot and delimit different subject positions and orderings of space. 
In the second chapter in particular, The Exhibitionary Complex, in his book Tony Bennett has focused on World Exhibitions as disciplinary institutions that order both the public and the nations on display. His text already represents a juxtaposition of museum history and exhibition history which is very useful. He ties the exhibitions explicitly to government policies and to the state. His ideas are used to understand how the Norwegian government was both inspired by and took advantage of the exhibitions to place itself on the side of the world's civilized peoples and on the side of the hegemonic powers. Bennett's claim concerning the civilizing effects of exhibitions is thus extended to the function of exhibitions internationally, influencing states other than those arranging the World Exhibitions.

The conclusion is that the study of exhibitions has much to gain from the theoretical framework developed in museology. This is not a new finding, but this particular application has not been made before. It is emphasised that the works of Bennett and Hooper-Greenhill are important in their combination of micro- and macroanalyses. They make interesting and important connections between the history of knowledge, bodies, artefacts and power. And they do it in a manner that is complementary and thus significant.

\section{NOTER}

1. Artikkelen baserer seg på et innlegg på seminaret "Om å forske på museum» arrangert av Institutt for dokumentasjonsvitenskap på Universitetet i Tromsø 14. okt. 1998. Det har i litt endrede versjoner også vært lagt fram på Forskerutdanningen ved HF-fakultetet ved Universitetet i Oslo og på Senter for teknologi og menneskelige verdiers metodeseminar høsten 1998. Takk for gode innvendinger som jeg nok ikke har fătt innarbeidet i tilstrekkelig grad. Også takk Kristin

Asdal, Gro Hagemann, Magdalena Hillström, Turid Markussen, Ingunn Moser og Erling Sandmo for lesning og/eller ulike typer utfordringer til å skrive om museer, metode og historie.

2. Fra en tale av prins Albert gjengitt i Henry Cole "Introduction" i Official, Descriptive, and Illustrated Catalogue of the Works of Industry of All Nations, London 1851, s. 4.

3. James Clifford: The Predicament of Culture, London 1988. s. 145-146.

4. "Kulturelle kamper om nasjonal identitet. Norge på utstilling 1851-1914». Dr.art.-prosjekt støttet av Norges forskningsråd.

5. Utstillingen i Lisboa var for stor og mine to dager der for korte til at jeg kan gi noen systematisk oversikt over utstillingen. Ta derfor mine betraktninger for det de er: en tilskuers opplevelse av verdensutstillingen. Forøvrig gjelder dette også min befatning med det forrige århundrets utstillinger, de var alt for omfattende til at et autoritativt overblikk både kan oppnås og formidles.

6. Ole Jacob Broch: «Industriudstillingen i London» i Illustreret Nyhedsblad, 11852.

7. Walter Benjamin: «Paris, det XIX. århundres hovedstad» i Kunstverket i reproduksjonsalderen. Essays om kultur, litteratur, politikk, oversatt av Torodd Karlsten. Oslo1975. Side 85.

8. Dette er en observasjon Margit Mogensen kom med i forbindelse med Expo'98 i Lisboa.

9. Se for eksempel Carsten Paludan-Müller: "Museums Betydning - den fraktale utfordring». Nordisk Museologi 1/1995, Tony Bennett: The Birth of the Museum, History, Theory, Politics, Routledge London 1995.

10. Det finnes etter hvert forskning basert på de fleste av disse perspektivene. For det første har det kommet oversiktsverk over verdensutstillingenes historie, som John Allwoods The Great Exhibitions fra 1977 - en bok som gir kortfattede 
60 og begivenhetsorienterte framstillinger i ord og bilder av de store utstillingenes historie. Senere har det kommet mer problematiserende og teoretiske framstillinger som Paul Greenhalghs Ephemeral Vistas, The Expositions universelles, Great Exhibitions and World's Fairs 1851-1939 fra 1988. Han følger enkelte hovedtemaer gjennom de ulike utstillingene, og er opptatt av hvordan politikk og makt kommer til uttrykk på utstillingene. En annen er Robert Rydell, som i boka All the World's a Fair: Visions of Empire at America's International Expositions 1876-1916 fra 1984 har sett på utstillingene som hegemoniets triumfer - steder der de mektige fikk spredd sine verdensbilder. Det er også gitt ut i alle fall tre forskjellige bøker til hjelp for forskere på utstillingsrelaterte emner: John E. Findlings Historical Dictionary of World's Fairs and Expositions 18511988 fra 1990, Brigitte Schroeder-Gudehus og Anne Rasmussen: Les fastes du progrès: Le guide des expositions universelles 1851-1992 Paris 1992, og Robert Rydell: The Book of Fairs fra 1992. Men forskning på utstillinger har også nedfelt seg i en rekke forskjellige utgivelser som tar opp enkeltutstillinger, enkelttemaer eller utstillinger sett fra enkeltlands eller enkeltgruppers synsvinkler. Fra et nordisk perspektiv er også utstillingene bredt dekket: Margit Mogensens bok Eventyrets tid, Danmarks deltagelse i verdensudstillingerne 1851-1900 fra 1993 er en empirisk orientert framstilling av Danmarks utstillingsdeltakelse i hele perioden. Tre enkeltartikler som sammen med boka utgjør hennes doktoravhandling, går nærmere inn på avgrensete perspektiver for å belyse den danske deltakelsen: teknologioverføring, reklame og kolonialisme. Kunsthistorikeren Kerstin Smeds har i boka Helsingfors-Paris. Finland på världsutställningarna 1851-1900 gitt en kulturhistorisk behandling av den finske deltakelsen, i forhold til kulturkonflikter, til økonomisk og teknologisk modernisering og til modernitetserfaringer. Særlig legger hun vekt på en utforskning av nasjonalismens vekslende innhold og uttrykk i den finske deltakelsen. Sverige har også fått sin utstillingshistorie beskrevet, fra et teknologi- og økonomihistorisk synspunkt, Göran Ahlströms Technological Development and Industrial Exhibitions 1850-1914. Sweden in an International Perspective, som bruker kildemateriale fra verdensutstillingene til å måle den relative stillingen til svensk industri i forrige århundre. Idehistorikeren Anders Ekströms Den utställda världen fra 1997,om Stockholmsutstillingen i 1897, behandler også 1800-tallets utstillingsbevegelse mer generelt.

11. Ingeborg Glambek: Kunsten, nytten og moralen. Kunstindustri og husflid i Norge 1800-1900, Oslo 1988. s. 71.

12. Se for eksempel Bennett og Eilean HooperGreenhill som jeg presenterer siden.

13. Se Rydell 1984 og Bennett.

14. Se for eksempel Bjarne Stoklund «International Exhibitions and the New Museum Concept in the Latter Half of the Nineteenth Century» $\mathrm{i}$ Ethnologia Scandinavica, vol.23, 1993.

15. Disse er hentet fra ulike nummer av tidsskriftet Nordisk Museologi. Nytelse fant jeg ikke der, men det må stå i en artikkel jeg ennå ikke har lest.

16. NOU 1996: 7. Museum. Mangfald,minne, møtestad. Kap. 5 fra nett: http://odin.dep.no/nou/1996-7/kap5.htm.

17. Eilean Hooper-Greenhill: Museums and the Shaping of Knowledge, London and New York, 1992. s. 8.

18. Hooper-Greenhill, s.8.

19. Samme sted.

20. Samme sted.

21. Hooper-Greenhill, s.2.

22. Erling Sandmo: «Æren og den borgerlige offentligheten: en musikkhistorie» i Dugnad 2/31998, vol. 24, s. 8.

23. Samme sted.

24. Frank Morton Todd: The Story of Exhibitions. New York 1921, sitert i Burton Benedict: The 
Anthropology of World's Fairs: San Fransico's Panama Pacific International Exposition of 1915. Berkeley 1983. Side 34.

25. Exposition Universelle de 1855. Le système de classification adopté par la commision impériale. Paris 1855. s. 3.

26. Prins Albert i tale sitert i Henry Cole i "Introduction" i Official, Descriptive, and Illustrated Catalogue of the Works of Industry of All Nations, 1851. London 1851. s. 22.

27. Se Cole «Introduction» og Yvonne French: The Great Exhibition, London 1950. Også behandlet i Brita Brenna: Disiplinerte drommer, Oslo 1996, kap.6.

28. Merk betydningen av ordet industri som knyttet til industriøs, arbeidssom, på denne tiden. Se Glambek. Merk også at industriutstillinger var et alternativt navn på de internasjonale utstillingene, men da ikke i den snevre betydningen vi i dag legger i begrepet industri.

29. Hooper-Greenhill, s. 214.

30. Exposition Universelle de 1867 à Paris. Catalogue général publié par la Commission impériale, 2. utg. Paris 1867. Innholdet i disse klassene er interessant slik de viste utvidelsen av en representerbar verden. Samtidig er det en fremmeartet verden vi møter, hvor ting og tanker kombineres på usedvanlige måter. For eksempel besto gruppe én av kunstverk, herunder oljemalerier, men også arkitektoniske modeller og planer. Gruppe to besto av materiale for og anvendelse av de liberale kunster. Herunder boktrykkerkunst, fotografi og sivile og militære ambulanser knyttet til medisinkunsten. Gruppe tre inneholdt møbler og andre produkter knyttet til boliger: Tapeter og møbelstoffer, klokker og parfyme var klasser i denne avdelingen. Grupper fire inneholdt klær, inkludert stoffer og andre objekter som en person bærer. I denne klassen fantes blant annet leketøy og bærebare våpen. Gruppe fem var råog bearbeidede produkter fra utvinningsindustrier. Gruppe seks besto av instrumenter og fram- gangsmåter for de 'vanlige' kunster (art usuels). Det vil si alle syv inneholdt friske eller konserverte næringsmidler, i forskjellige bearbeidelsesgrader: Sukker, bakevarer, godteri og alkohol. Åttende gruppe besto av levende produkter og eksemplarer fra jordbruksvirksomhet. Her fantes alle slags husdyr, men også nyttige insekter, fisk og skalldyr. Niende gruppe omfattet levende produkter fra hagebruksvirksomhet. Gruppe 10 har i ettertid blitt stående som den store nyvinningen: Her ble gjenstander utstilt spesielt med det for øyet å heve den fysiske og moralske tilstanden til befolkningen. Undervisningsmateriale for barn og voksne, og billige kvalitetsprodukter for bekledning og hjem, men også eksempler på folkedrakter fra ulike land, og billige boliger, hygieniske og forbundet med velvære. I tillegg var det klasser for mesterstykker laget av arbeidere og for deres arbeidsinstrumenter.

31. Arthur Chandler: "Paris 1867. Exposition Universelle» i Findling 1990, s.42.

32. "Den norske Central-Komitees Indberetning om Norges Deltagelse i Verdens-Udstillingen i Paris 1867», Stortingsforhandl. 1869. S. No. 85. s.21.

33. Indstill S. No. 72. Stortingsforhandl. 7D 1854. S. 370-1. "Det er desværre en ubestridelig Sandhed, at Norge er lidet bekjendt i Europa som eget og selvstændigt, hvilket, i flere Henseender skadeligt, under visse politiske Combinationer kan lede til Resultater, som for os skulde blive yderst bedrøvelige. Det er derfor i vor vel forstaaede Interesse at framstille os $\mathrm{i}$ Nationernes Række med Beviser for vore Fremskridt i Civilisation og Industri.»

34. Karen Marie Fjeldstad: «Nu skal Slaget atter stande: Som paa Hafursfjordens Vandee...» En kulturhistorisk undersøkelse av tre norske industriutstillinger 1873-1898. Hovedoppgave i historie UiO. Våren 1998.

35. Hooper-Greenhill, kap.7.

36. Bennett, s.5. 
BRITA BRENNA

62

37. Bennett, s.6.

38. Bennett, s.61.

39. Bennett, s.62.

40. Bennett, s.63.

41. Bennett, s.66.

42. Bennett, s.67.

43. Bennett, s. $87-88$

44. Bennett, s.67.

45. Bennett, s.73.

46. Bennett, s.80-81.

47. «My concern in this book is largely with museums, fairs and exhibitions as envisaged in the plans and projections of their advocates, designers, directors and managers. The degree to which such plans and projections were and are successful in organizing and framing the experience of the visitor, or, to the contrary, the degree to which such planned effects are evaded, sidestepped or simply not noticed raises different questions which, important though they are, I have not addressed here.» s.11.

48. Ole Richter i Stortingstidende 1866.

49. Beretninger om Norges Deltagelse i verdensutstillingen i 1878 i Paris. Kristiania 1880.

Brita Brenna er cand.philol. i idéhistorie. Ph.D.-student på Senter for teknologi, innovasjon og kultur ved Universitetet i Oslo med prosjektet "Kulturelle kamper om nasjonal identitet. Norge på utstilling 1851-

1914”. Interesse for feministisk vitenskapsteori, kulturstudier og studier av materiell kultur.

Adr: Senter for teknologi og menneskelige verdier (TMV), Gaustadalléen 21, N-0371 Oslo

Email:britab@tmv.uio.no 